Animal Twilight by J. L. Cloudsiey-Thompson. G. T. Foulis, 36s, The book's sub-title Man and Game in Eastern Africa is certainly more appropriate than the title, which suggests a narrative outlining the steady decline of wildlife populations, due primarily to the impact of man. Under discussion is Africa east of longitude $25^{\circ}$ East, a region which formerly supported herds of ungulates, great and small, in such incredible numbers that 'millions' was no exaggeration. Three chapters, The Impact of Man, The Changing Scene and Game Conservation, are the most important, but the general presentation is awkward, and the theme, though offering a wealth of informative and interesting detail, lacks continuity. But this defect of method does not detract from the ethnic, historical and zoological value of a work based on the consultation of nearly two thousand books of reference. In so vast a region it is obvious that, without intimate knowledge of local conditions and the vagaries of traditional hunting, important items will inevitably be missed. The initial trade in savage wild animals developed partly as a matter of prestige, but mostly to stage sickening man-and-beast gladiatorial spectacles, or cruel beast-to-beast combats rarely individual animals, often in dozens, sometimes hundreds. Also, though well known that elephants, both Asian and African, frequently figured in the armies of ancient times, who knows that $\mathbf{9 0 0 0}$ war elephants were once part of an Indian army?

The enormous economic potential of wildlife is stressed, not only for tourism, but for the planned cropping of the wild ungulates, which in circumstances adverse to domestic stock could ensure that land is put to the most economic and efficient use. Why destroy tens of thousands of immune ungulates as a tsetse-control measure when they can be profitably cropped to provide muchneeded protein?

There are some fine illustrations, and the 15 historical drawings - all reproductions - are excellent.

C. R. S. PITMAN

\title{
Vanishing Wild Animals of the World by Richard Fitter. Midland Bank and Kaye \& Ward, 30s. \\ Extinct and Vanishing Animals by Vincenz Ziswiler. Longmans \& Springer, 35s.
}

The first of these books devotes its royalties to the World Wildlife Fund, the second is recommended by it. Both are excellent value. Despite the similarity of title they are very different, and in some respects complementary.

The first is handsome, coffee-table, a pleasure to look at and to possess, with a foreword by HRH the Duke of Edinburgh and an introduction by Peter Scott. Appropriately to its title, it concentrates particularly on the species and their status, discussing them by continents, though there is also discussion fore and aft - of the causes of extinction and methods of conservation. Its splendid full-colour illustrations depicting rare animals in their habitats, painted by John Leigh-Pemberton, reproduce well on the large page. On the other hand, despite good type lay-out, the size is a little large for comfortable reading of the text, which, as may be expected from its author, is well written, full, balanced and reliable.

The second volume is small and slim, an excellent introduction to the subject that would be especially handy in schools. It concentrates on the general aspects of extinction and conservation, which it sets out and analyses clearly, being stronger on this than on the particulars of species. The small black-and-white illustrations and diagrams are numerous, well-chosen and appropriate, relating closely to the text. The translation from German, although plain enough, is not 
always happy in its English, nor is the writer quite so careful in expressing his own meaning.

It is ungenerous to niggle at two such useful books; nevertheless some faults should be pointed out. There is no harm in confining 'Animals' in the title of the first to its pop sense as 'Mammals', but page 22 is a little late to tell us that this is what the book is going to do. The distribution maps attached to the coloured pictures are an excellent idea, but in some cases the contrast with the caption is absurd. For example, the caption to the aye-aye says that 'some score or 20' may survive, nine individuals on one islet; the map shows no islet but five other locations which at this rate would have two point something animals each. In the Ziswiler book the Appendix list of species in danger is badly set out; to print English and Latin names in the same type is confusing. The selection of species is highly arbitrary-South American forms are much under-represented for example. And on what evidence are the wild horse and wild camel alleged to be subject to slaughter for meat and fat?

Both books display the giant panda on their dust covers. Fitter rightly notes in his text that it is not in peril, but Ziswiler includes it in his Appendix as among the 'most gravely threatened' although he has to leave the column of dangers to it completely blank. Actually, of course, it is rare, but neither extinct nor vanishing. On the other hand neither author says much or anything about the African leopard and the Indian tiger and the common Indian monkeys - nor does Ziswiler, who should, even mention crocodiles or any alligator but the Chinese all of which are certainly doomed, and within a very few years, if the toll of the laboratories and the fur and skin trade are not checked. At what exact figure would it have been right to begin to be anxious about the passenger pigeon and the western 'buffalo'? Surely an animal should qualify for the label 'vanishing' on the basis of its rate of decline, rather than by being stably rare or of a picturesque appearance.

The major weakness I find in these two otherwise excellent books is common to many others on the subject. Neither, in its examination of causes and remedies, really faces up to the fact that conservation is as much a responsibility of our own sophisticated populations as of those of the undeveloped territories in which the animals actually live. There is too much glib talk of policing countries far away when what we ought to be doing is making the dealing in vanishing animals and the wearing of their products crimes punishable in our own. Also, if we want to ask hungry locals not to kill walking bags of protein that pass by their villages, we must be ready to tax ourselves for aid programmes before we well-fed peoples claim restraint from those who are less well-off.

IVOR MONTAGU

The Apes by Vernon Reynolds. Cassell, 63s.

\section{A Handbook of Living Primates by J. R. Napier and P. H. Napier. Academic Press, 126s.}

The study of the primates is a growing point in biology, for their nearness to man, who has not always been too keen on recognising his poor relations, throws increasing light on that most important but most neglected of all disciplines, human behaviour. In this connection primates means not archbishops but apes and monkeys, and also marmosets, lemurs, lorises, tarsiers and perhaps tree-shrews (the experts are currently at odds over the relationships of tree shrews). Both books are most valuable contributions.

Dr Reynolds, one of our leading students of animal behaviour who has spent a great deal of time with chimpanzees in the field, distils from his experience an admirable summary of the natural history of the apes, gorillas, chimpanzees, 